\title{
Legal Policies for Non-Subsidized Hajj Financing in Indonesia*
}

\author{
Ahmad Mukri Aji, ${ }^{1}$ Muhammad Ishar Helmi² \\ Universitas Islam Negeri Syarif Hidayatullah Jakarta \\ $\underline{10.15408 / j \mathrm{jch} . v 9 \mathrm{i} 3.23686}$
}

\begin{abstract}
.
Additional quotas for hajj have not been resolved, particularly in regard to the financing of hajj, which requires subsidies. The state's goal of distributing subsidies to those who are unable to afford them has not been met, and the state's concept of welfare democracy has not been realized. Accordingly, this investigation employs normative legal research in order to focus on government policies as well as developing issues related to Hajj financing. A constitutional practice that has gradually become law is revealed in this study, namely the existence of subsidies created by the existence of benefit value instruments and the practice of subsidies that have been carried out previously in an indirect manner by the Minister with agreement from the DPR in determining BPIH by applying a $50 \%$ discount to the real cost of the hajj. As long as the constitutional practice is carried out in order to complete, perfect, and revitalize the legislation, this is normal. A formal legislative body or statutory regulation is required if there are any actual or potential constitutional issues with the practice of constitutional law.

Keywords: Open Legal Policy, Hajj Financing, Non-Subsidized Hajj, Hajj Category.
\end{abstract}

* Received: April 29, 2021, revised: May 15, 2021, accepted: November 19, 2021, Published: December 22, 2021.

${ }^{1}$ Ahmad Mukri Aji is a Senior Lecturer in the Faculty of Sharia and Law, UIN Syarif Hidayatullah Jakarta. ORCID ID: http://orcid.org/0000-0002-9802-5630. Email: mukri.aji@uinjkt.ac.id

${ }^{2}$ Muhammad Ishar Helmi is a Lecturer in the Faculty of Sharia and Law, UIN Syarif Hidayatullah Jakarta. Email: izharhelmi@uinjkt.ac.id

*Corresponding Author: izharhelmi@uinjkt.ac.id 


\title{
Kebijakan Hukum Pembiayaan Haji Non Subsidi di Indonesia
}

\begin{abstract}
Abstrak.
Banyaknya tambahan kuota haji belum teratasi, terutama perihal pembiayaan haji yang memerlukan subsidi. Target subsidi yang seharusnya menjangkau masyarakat yang tidak mampu secara finacial dan konsep demokrasi kesejahteraan melalui instrumen subsidi yang digunakan oleh negara dalam hal ini belum terpenuhi. Penelitian ini menggunakan jenis penelitian hukum normatif dengan pendekatan perundang-undangan dan kasus sehingga analisis penelitian lebih menekankan kepada kebijakan pemerintah dan permasalahan yang berkembang mengenai pembiayaan haji. Temuan penelitian ini yakni, keberadaan subsidi yang tercipta dengan adanya instrumen nilai manfaat dan praktik subsidi yang secara tidak langsung, telah dilakukan sebelumnya melalui penetapan BPIH dengan besaran $50 \%$ dari real cost biaya haji yang dilakukan oleh Menteri dengan kesepakatan DPR, secara tidak langsung menjadi kebiasaan yang praktik ketatanegaraan yang telah berangsur-angsur lama menjadi hukum. Hal ini adalah lumrah, karena selama kebiasaan ketatanegaraan dilakukan demi melengkapi, menyempurnakan, menghidupkan kaidah-kaidah hukum perundang-undangan, hal tersebut konstitusional. Namun jika praktik ketatanegaraan tersebut justru mengalami permasalahan atau potensi konstitusional, maka hal tersebut harus dipertegas dalam sebuah legis formal atau peraturan perundang-undangan.

Kata Kunci: Open Legal Policy, Pembiayaan Haji, Haji Non Subsidi, Kategori Haji.
\end{abstract}

\section{Правовая политика для не субсидируемых Финансирование хаджа в Индонезии}

\begin{abstract}
Абстрактный.
Дополнительные квоты на хадж не решены, особенно в отношении финансирования хаджа, который требует субсидий. Задача государства по распределению субсидий среди тех, кто не может их себе позволить, не была достигнута, а концепция государственной демократии всеобщего благосостояния не была реализована. Соответственно, в этом расследовании используются нормативно-правовые исследования, с тем чтобы сосредоточить внимание на государственной политике, а также на разработке вопросов, связанных с финансированием хаджа. В этом исследовании раскрывается конституционная практика, которая постепенно стала законом, а именно наличие субсидий, созданных наличием инструментов оценки выгоды, и практика субсидий, которые ранее осуществлялись косвенным образом министром с согласия ДНР. при определении БПЖ путем применения 50\% скидки к реальной стоимости хаджа. Пока конституционная практика осуществляется с целью дополнения, совершенствования и оживления законодательства, это нормально. Официальный законодательный орган или законодательное регулирование требуется, если есть какие-либо фактические или потенциальные конституционные проблемы с практикой конституционного права.

Ключевые Слова: открытая правовая политика, финансирование хаджа, хадж без субсидий, категория хаджа.
\end{abstract}




\section{A. INTRODUCTION}

The manifestation of the existence of the implementation of the Hajj in Indonesia is one form of the state's obligation to guarantee the independence of its citizens to embrace and worship according to their respective religions. In line with this, the Hajj which is embodied in Law No. 8 of 2019 concerning the Implementation of Hajj and Umrah (UU PIHU) is a regulation that regulates the role of the state in fulfilling the guarantee of worshipping its citizens in the form of the implementation of Hajj organized by the state through tools completeness.

The PIHU Law explains that the Hajj is carried out by dividing it into two categories, namely the Hajj with the regular category and the Hajj with a special category. Regular Hajj itself is defined as the organization of Hajj carried out by the Minister with management, financing, and services of a general nature. Meanwhile, for the special Hajj, the Hajj is carried out by the organizers of the Hajj, which is carried out by the Special Hajj Organizer (PIHK) with special management, financing, and services (See: Pasal 1, 11 UU No.8/2019).

The fundamental difference between the two categories of Hajj is in the organizers and management of Hajj funds. If during the regular Hajj, the management of funds and the implementation of the Hajj is carried out by the Government, while for the special Hajj, the implementation of the Hajj is carried out by a legal entity that has permission from the Minister to carry out a special Hajj, or in other terms, this organization is carried out by business entity in the form of travel (See: Pasal 10, Pasal 57 UU No.8/2019).

Another disparity between regular and special Hajj is in the payment and time period. In regular Hajj, the fees charged to citizens are relatively cheap, while in special Hajj the fees charged to citizens are relatively expensive. Meanwhile, for the waiting period, the special Hajj is faster than the regular Hajj. This is based on the fact that the price or special hajj fees paid by the special hajj pilgrims are four times the regular hajj costs.

This can be seen, when the special Hajj pilgrimage costs in 2020 amounted to eight thousand United States dollars (USD 8,000) or the equivalent of around 120 million rupiah. Meanwhile, for the regular Hajj, there is no increase and remains at a nominal value of around 35 million rupiah based on an agreement between the Government and the House of Representatives from the total hajj fee of 72 million per pilgrim. This price difference has advantages for prospective pilgrims for special Worship besides the duration of the special Hajj is faster, the services received by taking a special Hajj are also different as well as special facilities and services. 
The conception of the cost of organizing the hajj basically comes from several sources; namely sourced from Hajj Travel Costs (BIPIH) or an amount of money that must be paid by citizens to perform the Hajj, State and Expenditure Budget (APBN), Benefit Value, Efficiency Fund and other legal sources based on statutory regulations (See: Pasal 44 UU No.8/2019). In organizing the regular Hajj, the Government implements a subsidy mechanism for citizens who want to perform the Hajj. It can be seen in the cost of organizing hajj in 2020 in the amount of around 70 million rupiah, but the public only pays 35 million rupiah (lombokpost.jawapos.com).

Citizens who take the regular category of Hajj, basically get a subsidy from the Government to cover the shortfall of $50 \%$ of Hajj payments. The subsidy comes from Value Benefits and Efficiency Funds. The value of the benefits is obtained from the management of Hajj financial funds through placement or investment (See: Pasal 1 UU No.8/2019). In other words, the Benefits Value derives from the development of Hajj finance by the Hajj Financial Management Agency (BPKH) through the establishment of Sharia Banks, Sharia Business Units, and/or investments that adhere to Sharia principles regarding security, prudential management, benefit valuation, and liquidity (See: Pasal 46 UU No.34/2014).

This concept can be in the form of banking products, securities, gold, direct investment and other investments. However, all of them still pay attention to the principles of sharia and the benefit of Muslims (See: Pasal 48, 3,10,17,26 UU No.8/2019). Thus, the results of the development of Hajj finance come from sharia-based placements or investments, which become a subsidy for the $50 \%$ shortage of Hajj costs required when citizens take the regular Hajj. However, for the special conception of Hajj, it does not use subsidies. Hajj funds originating from citizens who take special Hajj services, as well as other Hajj financial management, are also carried out by the placement and investment process carried out by BPKH.

The amount of such a subsidy (50\%) causes a major potential problem, namely the money budget from the management or the value of the BPKH benefits cannot be sufficient for a situation where in the event of an economic crisis or an increase in the hajj quota. As in 2019, the hajj costs reached 7 trillion with a real hajj fee of 70 million, regular Hajj pilgrims who only deposit 25 million rupiah with an average waiting period of 10 years, will result in the management of these funds around 15 million rupiah. This condition ends in subsidies that will be carried out in the amount of 30 to 35 million rupiah. In fact, in the same 
year, there was an addition to the Hajj quota from the Government of Saudi Arabia as many as 10,000 pilgrims.

The crisis over the additional quota cannot be fully resolved by BPKH, so it requires an injection of funds that are re-issued by BPKH outside of the predetermined subsidies of 220 billion from BPKH and 99 billion from the Ministry of Religion through the efficiency of various activities (www.merdeka.com). The injection of funds from BPKH and the Ministry of Religion was primarily motivated by the concept of subsidizing hajj funds through other hajj registrant funds derived from the value of management benefits on placements, whether investments or deposits in the sharia aspect, which was insufficient to cover the additional quota received from the Saudi Arabian government.

This could be repeated not only when the Government of Saudi Arabia provides additional quotas but in the event of a recession or economic crisis such as in the conditions of the Covid-19 pandemic. This crisis condition has hampered the pace of economic growth, thus causing the management of hajj funds at several places of investment or sharia deposits to experience problems, even though investment in sharia aspects is low risk. In the end, this situation caused the subsidy target carried out by BPKH to not be fulfilled due to this situation and ended in another injection of funds from various sources.

In line with this, there are only two categories of Hajj, namely Regular Hajj with subsidies and Special only, placing people who are financially capable, can still use subsidies through the categories of regular and subsidized Hajj. Such a conception indirectly with the presence of state injections through one of the efficiency of activities at the Ministry of Religion, apart from the cost of organizing the Hajj raises its own problems in the concept of Istitha'ah Hajj in the financial aspect.

On another aspect, the existence of the Hajj with only these two categories, also raises the problem of the issue of welfare democracy. This is because the main concept of welfare democracy carried out by the state through subsidies or assistance instruments that can be carried out by the state also experiences a misunderstanding if it only places regular Hajj services with subsidies and only special Hajj services. This is because the target or recipient subject of the subsidy should be people who are financially incapable but want Hajj, it is the responsibility of the state to carry out the subsidy with available instruments such as placement or investment on a sharia-based platform. 
On this basis, the government should implement a policy of nonsubsidized Regular Hajj in order to perfect the concept of Istitha'ah Hajj financially, particularly the subsidy target set by the state for Hajj implementation, in order to fulfil state guarantees and protection in respect of, protect, and fulfil the religious rights of all citizens, as stated expressis verbis in the 1945 Constitution (See: Pasal 28 (4) juncto Pasal 28E (1), 29 (2) UUD 1945).

Previous research has described the difficulties associated with hajj financing in Indonesia. Muhammad Rifa'at Adiakarti Farid discussed the Hajj bailout fund in his article, Problem or Solution? (Analysis of Policies for Hajj Implementation), PALITA: Journal of Social-Religious Research, Vol. 4, No. 2. (2019). There are numerous obstacles to organizing the hajj in Indonesia, including the issue of increasing hajj interest without accompanying improvements to hajj supporting facilities such as boarding, catering, passport and visa processing, which are frequently constrained by inefficient bureaucracy, separation of operators and regulators in carrying out hajj, and the like.

While the process of organizing the pilgrimage has improved significantly year after year, numerous issues remain that must be resolved immediately in order to fully implement and implement the state's primary service policy toward citizens. Hajj is a multifaceted, cross-sectoral public service administered by the Ministry of Religion. In terms of development and service quality, the Hajj bailout represents a new milestone in the implementation of the Hajj, which was previously halted due to numerous impediments. The most visible issue is the growing length of the Hajj queue, which can last years, if not decades.

\section{B. METHODS}

This research uses normative legal research with a statutory and case approach. In this study, the authors examine Law Number 34 of 2014 concerning Hajj Financial Management and Law Number 8 of 2019 concerning the Implementation of Hajj and Umrah. The Law on Hajj Financial Management and the Law on the Organization of Hajj and Umrah, both of which currently do not contain details on the subsidy concept scheme. The concept of a subsidy is only implied when there is a Hajj Pilgrimage fund that registers with an initial deposit which will be managed as a benefit value and accompanied by state administration practices between the House of Representatives (DPR) and the Government in the form of regular Hajj fees with a payment percentage of half of the real cost. 


\section{RESULTS AND DISCUSSION}

\section{The Problems of Indonesian Hajj in the Financial Aspects of Hajj Istitha'ah}

Although Hajj, as one of Islam's pillars, is an obligation for Muslims to Allah SWT, there is an exception, namely the existence of people who are able or capable (Istitha'ah). This is clearly stated in the Qur'an in verse 97 of the letter AlImran.

"It contains manifest signs, among which is Ibrahim's station; whoever enters it the Baitullah) will be safe; Hajj is a human obligation to Allah, specifically for those who are able to travel to the Baitullah. Whoever denies (the Hajj obligation), Allah is indeed Rich (does not require anything) in the universe."

Additionally, the Prophet clarified the meaning of Istitha'ah as follows (Rajab, 2014): From Abdullah bin Umar bin al-Khattab ra., that someone came to the Messenger of Allah and asked: "What makes Hajj obligatory?" Rasulullah replied: provisions and vehicles.' (HR. al-Tirmizi).

In accordance with this, Sayyid Abu Bakr bin Muhammad Syatho defines Istitha'ah as follows in the Book of I'anatut Thalibin: "And a person is said to be istitha'ah if he has access to travel provisions and a means of subsistence for his dependent family (Kisworo, 2017)." Nasr Farid Wahsil concurs as well. In terms of finances, Nasr Farid Wahsil believes that the letter QS. Ali-interpretation Imran's in terms of the pilgrimage's ability to signal that it is a once-in-a-lifetime activity when all conditions (wealth and health) are met is correct. Property is considered to be in good condition when a Muslim is able to pay for himself and the people for whom he is responsible.

Thus, it is not obligatory for a Muslim to perform Hajj if he does so through instalment debt in order to avoid being excessive in Hajj (abandoning other needs). Indeed, he has fallen under the obligation of Hajj, as this obligation requires the ability (istitha'ah) (Rajab, 2014). Financial capability to perform Hajj can also be interpreted as not just personal financial capability; if a community or community group collaborates to finance one of them to perform Hajj, this is legal even if they are personally unable to fulfill their Hajj financial obligations. This must also adhere to several provisions, including the absence of coercion and the absence of usury (Yahya, 2007), (Rizal; Yusriando, 2020).

Regular Hajj subsidies are included and begin with Article 48 of the PIHU Law. According to Article a quo, the President determines the amount of the Hajj Organizing Fee (BPIH) after the DPR approves the BPIH proposal. The BPIH is funded through the community's Hajj Travel Costs (Bipih), the value of benefits, the Efficiency Fund, and other legitimate sources, in addition to the APBN (See: 
UU No.8/2019). As was the case in 2019, the average real hajj cost was 69.7 million rupiah. The DPR and the President agreed to set the cost of regular hajj or BPIH at an average of 35.2 million rupiah. This condition causes the subsidy carried out by BPKH to be almost $50 \%$ of the total cost of hajj.

When the quota was increased to almost $50 \%$ in the same year (2019), the nearly $50 \%$ subsidy resulted in the hajj finances managed by BPKH being deducted from the value of the benefits provided for the subsidy, which turned out to be in excess of what was set. Indeed, BPKH issued funds for the additional quota alongside funds issued by the Ministry of Religion as a result of the Ministry's own efficiency.

Such conditions within the framework of the Hajj in Indonesia, with the categories of regular Hajj with subsidies and special Hajj, have increased the possibility of not adhering to the istitha'ah concept or a person's ability to adhere to the financial requirements of the Hajj. This is because one of the funding sources for the Hajj is the efficiency of the Ministry of Religion's budget.

This scheme is revealed indirectly when the Hajj uses funds from the Ministry of Religion, which are primarily intended for the organization of the Hajj (rather than a budget to support the Ministry of Religion's performance), because the funds are not entirely derived from the management of Hajj funds or from the value of benefits or finances of private Congregants deposited and held in the BPKH account.

Istitha'ah prospective pilgrims financially require Muslims to meet several conditions, including the absence of debt, as explained in the Hadith of the Prophet Muhammad narrated by Imam al-Baihaqi, namely "From Abdullah bin Abi Aufa, one of the Prophet's companions, said: "I asked the Prophet (s) about a person who has not yet performed Hajj, can he simply take on debt to go on a pilgrimage?" "No," the Prophet replied (Yahya, 2007), (Rizal; Yusriando, 2020).

According to hadith history, while the injection of funds from the Ministry of Religion is not considered a debt, it is classified as not coming from a private congregation or the management of a community congregation, which creates ambiguity regarding the validity of the Hajj.

In the event of a recession or economic crisis, the category of Hajj that only includes regular Hajj services with subsidies and special has the potential to cause a financial collapse in the management of Hajj. In terms of investment, one could argue that Hajj's financial management is not dissimilar to a Ponzi scheme, which operates by luring new investors (Prospective Jemaah Baru) with the promise of higher profits (cheap Hajj costs with subsidies) in the short term. 
Sustaining this investment requires funds to continue to flow in from new investors (www.sec.gov). Without a new investor, it is certain that this system or scheme will be destroyed, and businesses or those who use it will see a decline in the management of investor funds.

The Hajj, which is performed using conventional, subsidized, and special instruments, is actually quite similar to a Ponzi scheme, if the two categories are maintained. This is because the Hajj organization utilizes an investment or deposit management scheme that rewards pilgrims who have recently registered with benefit values that will be enjoyed by pilgrims (investors) who have registered for a long period of time even though they still have a long wait. Thus, when there are no or few people registering for Hajj, it is unavoidable that the financial management of the Hajj in the form of the benefit value suffers disruption, if not a deficit, due to the inability to add sharia deposits or investments to the benefit value. Such a situation could also result in a deficit in the BPKH in the event of an Indonesian recession or economic crisis.

Dependence on new registrants (new congregations) and the establishment of a subsidy scheme for Hajj management carries a very high risk, despite the fact that the majority of Indonesians are Muslims. Although the placements are made in low-risk Islamic deposits or investments, the primary focus of Hajj financial management remains on citizens who continue to register as prospective pilgrims, with a secondary focus on sharia investment containers and Indonesia's economic growth conditions.

When there is a shortage of BPIH and it is covered by multiple sources of funding from the APBN or the Ministry of Religion, there is ambivalence, although there are several ways to smooth this out formally. As with the President's budget realignment in response to the Covid-19 pandemic via the Perppu (See: UU No.2/2020). While this is technically permissible, it will raise the issue of Istitha'ah from the congregation regarding the Hajj conditions, as it does not stem from the congregation's financial ability.

As a result, if the categories of regular Hajj with subsidies and special Hajj are maintained without any development or other concepts other than the regular subsidized and special Hajj, the problematic Istitha'ah contained in the conditions for the validity of the Hajj has the potential to invalidate the Hajj. On the other hand, if this investment scheme is used to manage hajj funds, then BPKH's financial management of hajj may collapse, either as a result of at least one pilgrim registering for hajj (due to reliance on prospective pilgrims) or as a result of a recession or economic crisis. These two issues essentially create a new 
spectrum of issues regarding the state's ability to guarantee citizens' rights to religion and worship, as guaranteed in the 1945 Constitution.

\section{Ambivalence of Welfare Democracy Principles in Hajj Subsidy}

The Indonesian national economy is fundamentally a reflection of Pancasila's values, particularly the fifth precept, which states that justice is social justice or mutual cooperation, rather than individual justice, which is highly subjective. This paradigm is not merely rhetoric; it has a significant impact, namely that democracy is not only absolute and based on consensus, but also on deliberation, by returning to the concept of the general welfare.

This axiom was historically affirmed by Soekarno's opinion in the BPUPKI session minutes, which stated:

"We want social justice... The Grondwet which contains “Droit de l'homme et du eitoyen" cannot eliminate the hunger of poor people who are about to starve to death. Therefore, if we really want to base our country on the idea of kinship, the idea of helping, the idea of mutual cooperation and social justice, get rid of every thought, every idea of individualism and liberalism thereof (Yamin, 1959)."

Soekarno's desire for a state based on mutual cooperation was perfectly captured in Article 33 paragraph (1) of the 1945 Constitution, which stated explicitly that the economy was structured as a collaborative effort based on the kinship principle. This concept is reflected in a postulate of welfare democracy, which is based on the adage Salus Populi suprema lex.

The general welfare principle's approach is based on two fundamental concepts: communitarianism and equality (Manan; Harijanti, 2014). This principle emphasizes the existence of equality in all spheres of social life by placing a premium on collectivism over individualism. This principle is embodied in a mechanism for capitalism's acceptance and, on the other hand, is a system of wealth distribution that is guided by moral principles rather than market principles (Manan; Harijanti, 2014). Therefore, a state that applies the principle of welfare, suppresses the existence of social security and special treatment (Sayuti, 2013). Apart from that, it is concerned with the welfare of vulnerable and weak communities, one of which is the Indonesian state, which enacts it via the 1945 Constitution (Manan; Harijanti, 2014).

Indonesia's implementation of democratic welfare principles is also reflected in the organization of the Hajj. The gotong-royong principle is demonstrated by the existence of citizens who wish to perform regular Hajj 
services while receiving subsidies. However, in practice, the subsidy principle is misguided due to the scarcity of Hajj services; currently, there are only regular Hajj services with subsidies and special Hajj services. This category indicates that those who can afford it may also choose to perform the regular Hajj with subsidies.

The welfare principle, which incorporates the fundamental concept of equality, is not reflected in the Hajj, which focuses exclusively on subsidized and special regular Hajj services. Because in the concept of equality, only the economically vulnerable and weak receive subsidies or preferential treatment in order to achieve equality with economically stronger groups. The contextualization of regular hajj with subsidies without any classification of vulnerable groups receiving subsidies demonstrates that the welfare principle's concept of equality is not being realized, as this will continue to lengthen and also widen the economic divide between the poor and the wealthy.

Although Hajj is an obligatory pillar of Islam, it requires the existence of a state that functions to respect, protect, and fulfill each citizen's human rights, particularly the right to worship according to their respective religions and beliefs. This is the government's obligation, particularly when it comes to providing preferential treatment in the form of subsidized hajj funds to vulnerable or weak groups (economy) in order to achieve parity with wealthy groups (Smith; et.all, 2008).

As a result, if the state organizes the Hajj while maintaining these two categories, the state effectively denies vulnerable or economically weak community groups the right to worship and religion in accordance with their respective beliefs within the framework or principles of welfare democracy.

In light of this proposition, a new legal instrument or policy by the state is required to equate the principle of equality in subsidies for Hajj performed by the state. Because the law is a suggestion for engineering the social structure of society in the context of national development, including affirming the principle of equality (Latipulhayat, 2014).

One solution to these issues is to implement the concept of non-subsidized regular Hajj. The concept is to implement a standard, non-subsidized Hajj for the upper-middle-class community. This is demonstrated by financial conditions such as the job of prospective pilgrims, the congregation's assets, and the congregation's ability to pay for the pilgrimage's costs.

This concept emphasizes that by focusing on the upper-middle class for the non-subsidized regular Hajj and the lower middle class for the subsidized 
regular Hajj, the Indonesian state's principles of welfare and mutual cooperation will be implemented, as the target recipients of the subsidized Hajj funds are vulnerable and weak groups (economy). Meanwhile, in terms of hajj financial management, it is unavoidable to rely on the next pilgrim candidate to place investments and deposits in a sharia-compliant manner, without running the risk of a hajj financing deficit, so that the Hajj can still be performed during times of crisis or recession.

This concept has indirectly manifested the 1945 Constitution's contents through state actions in the area of special treatment (affirmative action) and subsidies to people with disabilities in order to achieve equality in the enjoyment of the right to religion and worship according to their respective beliefs and also to avoid the risk of using Hajj funds that are not budgeted for Hajj financial management, such as APBN or Ministry of Religion funds, which indirectly also contribute to the risk of using Hajj funds that are not budgeted for Hajj.

\section{Non-Subsidized Hajj is the Government's Open Legal Policy.}

The hajj scheme is divided into two categories: regular Hajj with subsidies and special Hajj services, as defined in Law No. 34 of 2014 on Hajj Financial Management and Law No. 8 of 2019 on Hajj and Umrah Implementation (Law 8 of 2019) (See: Pasal $1(9,10)$ UU No.34/2014). Subsidies are defined in Article 8 of Law 8 of 2019, which states expressly that the Cost of Hajj Operations (BPIH) is derived from Bipih, APBN, Benefit Value, Efficiency Funds, and/or other legal sources in accordance with applicable statutory regulations (See: Pasal 44 UU No.8/2019).

The benefits are calculated based on the financial management of the Hajj, which is funded by Bipih, Efficiency Funds, or other legitimate sources in accordance with statutory regulations (See: Pasal 8 UU No.34/2014). This management is the responsibility of BPKH. Hajj finances must be managed through Islamic Commercial Banks or Sharia Business Units. This can be accomplished through placements or investments that adhere to sharia principles, security, prudent benefit valuation, liquidity, and low risk (See: Pasal 46,47 UU No.34/2014).

In line with this, Hajj in 2019 will incur real costs of approximately Rp. 69.7 million on average, while prospective Hajj pilgrims will incur real costs of approximately Rp. 35.2 million on average. This demonstrates that there will be a subsidy of nearly Rp. 35 million to cover the real cost (news.detik.com). The development of Hajj financial management to cover actual costs is primarily 
accomplished through a sharia-compliant placement or investment scheme with the end result being the form or value of the benefit.

The Minister submits a proposal for the amount of BPIH to the DPR RI for further approval within a maximum period of 60 days after receiving the BPIH proposal, and if the Minister does not receive approval from the DPR for the current year's amount of BPIH, he uses the BPIH with the previous amount (See: Pasal 46 dan 47 UU No.8/2019).

Subsidies created by the existence of value-benefit instruments and the practice of indirect subsidies, which had previously been carried out by the Minister with the agreement of the DPR through the determination of BPIH in the amount of $50 \%$ of the real cost of hajj costs, indirectly became a habit that was a constitutional practice that had been gradually implemented long into law. This is natural, because constitutional practice is constitutional as long as it is used to complete, perfect, and revitalize laws and regulations (Manan, 1987).

However, if the constitutional practice actually encounters or has the potential to encounter constitutional problems, this must be highlighted in a formal legislature or statutory regulation. The current Hajj Financial Management Law, the Law on the Organization of Hajj and Umrah, as well as technical regulations, make no reference to the subsidy concept scheme. Subsidies are implied only when Hajj pilgrims register with an initial deposit that will be managed as a benefit value and accompanied by administrative practices between the DPR and the Government in the form of regular Hajj fees with a payment percentage equal to half the real cost.

Leaving this aside, reflecting on the formation of a law that is broad in scope and does not detail the concept of organizing the Hajj in order to allow for the existence of subsidies through state administrative practices or habits, requires the government to be expressis verbis in regulating the concept of organizing the Hajj in order to avoid financial deficits and to allow for the state's presence in administering subsidies.

The existence of a legal vacuum in resolving the issue of Istitha'ah, the management of hajj funds that may be in deficit, and the inappropriate target of the Hajj pilgrimage subsidy obligates the Government to initiate a formal legal process establishing a new category of Hajj pilgrimage with regular and nonsubsidized rates. The legal vacuum that continues to exist in implementing the concept of Hajj, which focuses exclusively on regular Hajj services with subsidies and specials, will continue to raise Istitha'ah concerns, most notably regarding the legal requirements for Hajj, demonstrating the state's negligence in 
guaranteeing citizens' rights to enjoy and worship according to their respective religions, as stated in the 1945 Constitution.

As a result, in order to expedite the resolution of these issues and wait for the process to be completed in the stages of the Law to formalize non-subsidized regular Hajj by the DPR, the Government as Chief Executive can make a good policy in the Regulation of the Minister of Religion to transform it into a regulation that provides non-subsidized regular Hajj services. After all, when the existing legal framework effectively violates citizens' religious rights, the state has committed human rights violations within the category of religious rights.

\section{CONCLUSIONS}

Due to the broad scope and lack of detail in the formulation of the Law on the concept of organizing the Hajj, subsidies through administrative practices or customs exist. This requires the government to expressis verbis regulate the concept of organizing the Hajj in such a way that the Hajj's financial management does not suffer a deficit and the state's presence in the administration of subsidies is possible. Additionally, the government's obligation to carry out a formal legal process in establishing a new category of Hajj pilgrimage with regular and nonstandard procedures subsidy is based on the existence of a recht vacuum in resolving the issue of Istitha'ah, the management of hajj funds that may be in deficit, and the inappropriate targeting of Hajj subsidies.

\section{REFERENCES:}

Aji, A.M. (2010). Rasionalitas ijtihad Ibn Rusyd: kajian atas fiqh jinayat dalam kitab "Bidayat al-Mujtahid wa Nihayat al-Muqtashid, Bogor: Pustaka Pena Ilahi.

Indonesian Constitution (UUD NRI 1945).

Kaelan, (2010). Pendidikan Pancasila, Yogyakarta: Paradigma.

Kisworo, Budi. (2017). "Ibadah Haji di Tinjau Dari Berbagai Aspek", Al Istinbah: Jurnal Hukum Islam, Volume 2, Nomor 1.

Latipulhayat, Atip. (2014). "Khazanah Roscoe Pound", Padjadjaran Jurnal Ilmu Hukum, Volume 1, Nomor 2.

Law Number 34 of 2014 concerning Hajj Financial Management.

Law Number 8 of 2019 concerning the Implementation of Hajj and Umrah. 
Manan, Bagir. (1987). Konvensi Ketatanegaraan, Bandung: Armico.

Manan, Bagir; And Harijanti, Susi Dwi. (2014). “Saat Rakyat Bicara: Demokrasi dan Kesejahteraan", Padjadjaran Jurnal Ilmu Hukum, Volume 1, Nomor 1.

Manan, Bagir; AND Harijanti, Susi Dwi. (2015). Memahami Konstitusi: Makna dan Aktualisasi, Jakarta: Raja Grafindo.

Mukri, S.G.; Aji, A.M.; Yunus, N.R. (2016). "Implementation of Religious Education in the Constitution of the Republic of Indonesia," Salam: Sosial dan Budaya Syar-i, Volume 3 No. 3.

Mukri, S.G.; Aji, A.M.; Yunus, N.R. (2017). Relation of Religion, Economy, and Constitution In The Structure of State Life, STAATSRECHT: Indonesian Constitutional Law Journal, Volume 1, No. 1.

Rajab, (2014). "Berhaji Dengan Dana Kredit: Kaji Ulang Konsep Istitha'ah Dalam Haji," Jurnal Tahkim: Volume X, Nomor 1, Juni 2014.

Rizal, Said; AND Yusriando, (2020). “Batasan dan Ukuran Istitha'ah dalam Berhaji Menurut Hukum Figh Kontemporer", Jurnal Ilmu Hukum Prima, Volume 3, Nomor 1.

Sayuti, Hendri. (2013). "Hakikat Affirmative Action Dalam Hukum Indonesia : Ikhtiar Pemberdayaan Yang Terpinggirkan", Menara, Volume 12, Nomor 1, Januari-Juni.

Smith, Rhona K.M. et.all, (2008). Hukum Hak Asasi Manusia, Yogyakarta: Pusat Studi Hak Asasi Manusia Universitas Islam Indonesia, PUSHAM UII.

Yahya, Imam Abu Zakariyya. (2007). Raudhatul Thalibin (terjemahan A. Shalahuddin, dkk.), Jakarta:Pustaka Azzam.

Yunus, N.R.; Anggraeni, RR Dewi.; Rezki, Annissa. (2019). "The Application of Legal Policy Theory and its relationship with Rechtsidee Theory to realize Welfare State," 'Adalah, Volume 3, No. 1.

Decree of the Director-General of Hajj and Umrah Organization Number 143 of 2020 concerning Guidelines for Payment for Repayment of Special Hajj Travel Expenses and Processing of Special Hajj Documents for 1441/2020M.

Decree of the Minister of Religion Number 140 of 2019 concerning Payment of Fees for the Implementation of the Regular Hajj 1440 H / 2019 M.

https://lombokpost.jawapos.com/nasional/05/06/2020/pemerintah-pangkassubsidi-biaya-haji-secara-bertahap/. 
https://news.detik.com/berita/d-4413836/dpr-menag-sahkan-biaya-haji-tahun2019-sebesar-rp-352-juta

https://www.merdeka.com/peristiwa/pemerintah-dan-dpr-sepakati-biaya-haji2020-tidak-naik-tetap-rp35-juta.html.

https://www.merdeka.com/uang/biaya-untuk-kuota-tambahan-10000-jemaahhaji-tak-gunakan-apbn.html.

https://www.sec.gov/fast-answers/answersponzihtm.html. (U.S. Securities and Exchange Commission). 